\title{
Development of Embryonic Chick Liver and Distribution of eNOS, iNOS, Laminin $\alpha 1$
}

\author{
Fatih Çöllü̈1, Beyhan Gürcü̈ ${ }^{1 *}$ \\ ${ }^{1}$ Celal Bayar University, Faculty of Science and Letters, Department of Biology, Zoology Section, Manisa, Turkey \\ byhgurcu@gmail.com* \\ ${ }^{*}$ Corresponding author \\ Received: $1^{\text {st }}$ March 2017 Geliş: 1 Mart 2017 \\ Accepted: $9^{\text {th }}$ May 2017 \\ DOI: $10.18466 /$ cbayarfbe. 305213
}

\begin{abstract}
At the embryonic development, signal transduction pathways, genetic factors, involvements between nucleus and cytoplasm, environmental factors, cell-cell and cell-matrix interactions have important roles. It has been known that the cells are regulating the Extracellular Matrix (ECM) synthesis, degradation and reshaping events, also it has been known that the Nitric Oxide is an important molecule for cellular communication and have effects on ECM molecule distribution by reacting with ECM molecules. In this reason, the purpose of our study is detecting the correlation of reactive nitrogen species with a glycosylated molecule laminin $\alpha 1$. In this experiment, Leghorn type SPF (Specific Pathogen Free) embryonic chick eggs have been used. Embryos are collected at $5^{\text {th }}, 6^{\text {th }}$ and $7^{\text {th }}$ days at incubation and taken into the $10 \%$ neutral buffered formalin solution. The liver tissues that dissected from embryos are fixated at second time. After 24 hours, it has been subjected to the routine paraffin embedding method and embedded to paraffin. From the $5 \mu \mathrm{m}$ sections, immunohistochemistry for eNOS, iNOS and Laminin $\alpha 1$ distribution, and for general histologic evaluation, Haematoxylene-Eosin stains has been applied. eNOS and iNOS immunoreactivity has been observed at peripheral zone of developing liver tissue that epithelialmesenchymal transition takes place. It has been determined that immunoreactivity was minimal in $5^{\text {th }}$ day, increasing with the days progressed and have highest at $7^{\text {th }}$ day. Also, eNOS staining has been more powerful than iNOS staining. Laminin immunoreactivity has been similar at all developmental stages, but relatively, has been showed lesser staining. Particularly, the presence at the zones of cell differentiation has been noteworthy.
\end{abstract}

Keywords - Liver development, eNOS, iNOS, Laminin, Liver development, Chick embryo.

\section{Introduction}

Liver is a big secretory organ that is in relation with almost all body systems and is functional within carbohydrate, protein and lipid metabolism, storage (carbohydrate, vitamin and iron), detoxification of harmful toxins, secretion and clotting factors [1]. Also, the liver is a unique organ in aspect of its regenerative capacity. Even after a big hepatectomy surgery, the remaining liver can repair itself [2]. With the embryonic development, liver is present and it takes a position between nutrition veins and circulatory system as a filtering and metabolic organ [3].

Embryonic development is based on the ability of cells that can produce tissues, possessing the abilities of differentiation, multiplication and morphogenesis. In this process, signal transduction pathways, heretic factors, the relationship between cell nucleus and cytoplasm, environmental factors, cell-cell and cell-matrix interactions have critical place [4].

Nitric oxide (NO), is an important molecule that has a role on secondary messenger system [5]. It can be synthesized from L-arginine catalyzed by nitric oxide synthase (NOS) enzyme [6], it has multiple physiological roles like defense against microorganisms and it is an inorganic molecule that is mainly synthesized from epithelial cells [7]. $\mathrm{NO}$ can act freely and radically in much physiological mechanisms and can react like superoxide and can produce harmful-free radicals [8]. Increased or decreased $\mathrm{NO}$ can be resulted with an increase or a decrease in reactive oxygen 
species production (ROS) [9], and in the actin and tubulin cytoskeletal elements; it can show an effect on mitochondrial voltage dependent anion channel (VDAC) and it can drive the cell to survival or apoptosis [10]. Also, the change of NO density can change TGF- $\beta$ and matrix metalloproteinase (MMP) expressions through cGMP; by affecting cGMP dependent protein kinases [11, 12]. Such changes on MMP and TGF- $\beta$ can lead to the remodeling of the Extracellular Matrix (ECM), and can result in the changes of cell movements and characteristics [11]. Changed NO density can also activate P53 gene and upon p21 pathway, it can affect mitochondria, induce caspases and can lead to cells to apoptosis [13] (Figure 1).

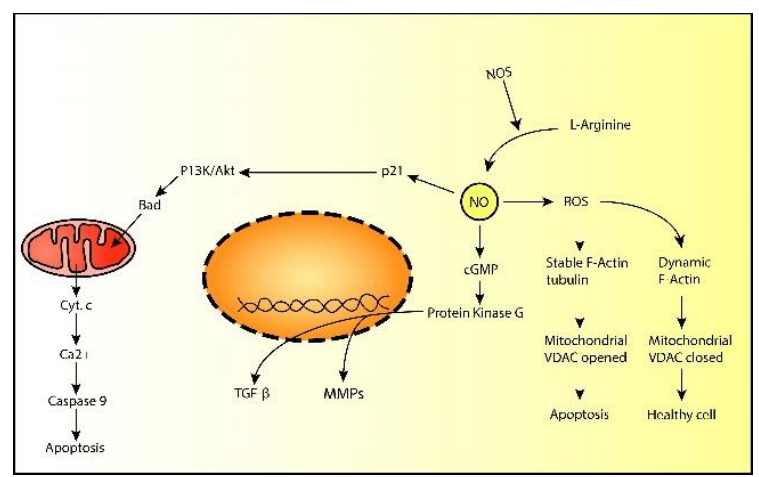

Figure 1. Intracellular NO effect mechanism [14].

ECM, has the dynamic abilities. The balance between synthesis and degradation of ECM components are extremely important for the transduction of signals that belong to development, continuation and shaping of tissue and organs for the organisms [15-19]. The publications being published nowadays indicate that the laminin and type IV collagen are responsible for structural integrity [20].

Laminin, has 18 types [21, 22] that are effective on biological activities like cell adhesion, cell migration, cell differentiation and cell proliferation [20]. Also, they are involved in ECM (polymerization, connecting to nidogens and other ECM molecules) and cell surface interactions (glycolipid, proteoglycan and glycoprotein, with the couple of receptor activities) [20]. It is known that these functions take place in the connections of localized cell surface receptors and ECM molecules [23, 24]. It has been known that the cells can regulate synthesis, destruction and the reshaping of ECM with the signals coming from outside $[25,26]$. Also, NO is an effective molecule for cellular communication and can affect ECM molecule distribution [27]. Because of this, NO has important roles on the cellular communication, development, cell differentiation and cancer [4]. Thus, the aim of this study is to detect the liver development and eNOS, iNOS and Laminin $\alpha 1$ distribution

\section{Material and Method}

In this experiment, Leghorn-type embryonated chicken eggs (SPF; Specific Pathogen-Free), taken by Turkey's Ministery of Agriculture and Farming, Bornova Veterinary Control and Research Institute Administration, have been used. This study is approved by Animal Experiments Regional Ethic Committee with number 77.637.435-21 in Celal Bayar University Faculty of Medicine.

Eggs have been incubated into the incubator that has $37.5 \pm 0.2^{\circ} \mathrm{C}$ temperature and $65 \% \pm 0.5$ humidity settings with cradle feature. In the $5^{\text {th }}$ (HH26), $6^{\text {th }}$ (HH28) and $7^{\text {th }}$ (HH29) days of incubation, eggs have been opened carefully and embryos taken out are fixated into the $10 \%$ neutral formalin solution. After fixation, dissected liver tissues have been dehydrated by transferring the tissues into the increased alcohol series. Tissues have been embedded into the paraffin after the clarification process performed with xylene. The 5 $\mu \mathrm{m}$ sections taken from paraffin blocks have been taken onto the microscope slides and for the determination of general structure, HaematoxylinEosin (SCBT, sc-24973) has been used, and for the examination of eNOS (SCBT, sc-654), iNOS (SCBT, sc-651) and laminin $\alpha 1$ (NOVUS, nb600-883), immunohistochemistry staining has been performed [28-30].

\subsection{Histological stain}

The sections are deparaffinized by xylol, are subjected to decreasing alcohol series and stained by haematoxylin after eosin stain. Then, they are subjected to increasing alcohol series, are cleared with xylene and mounted with coverslip by entellan [31].

\subsection{Immunohistochemistry Staining}

The sections taken onto the Lysine coated slides are deparaffinized in an oven at $60^{\circ} \mathrm{C}$ and clarified by xylol. After that procedure, sections have been rehydrated by decreasing alcohol series and taken 
into the distilled water. In the sections under the $0.5 \%$ trypsin solution, $3 \% \quad \mathrm{H} 2 \mathrm{O} 2$ has been administered. After washing with phosphate buffered saline (PBS) solution, the sections have been treated with blocking solution. Without PBS washing, primary antibodies (eNOS, 1/100 dilution; iNOS, 1/100 dilution; Laminin 1, 1/100 dilution) have been added and sections are incubated overnight at $+4{ }^{\circ} \mathrm{C}$. After PBS washing step, anti-hydrogen peroxidase secondary antibody is applied to the sections. After another PBS washing, the sections have been applied with diaminobenzidine tetrahydrochloride (DAB) solution for the visualization of immunohistochemistry reaction. After background staining with Mayer's haematoxylin solution, sections are washed with distilled water, dehydrated by alcohol, clarified with xylene and mounted with coverslips by entellan mounting medium [32]. Handled slides are then investigated in bright field microscope and photographed by Olympus (DP73) camera.

\section{Results}

The embryonic chick liver samples prepared and stained by histological methods have been examined and photographed.

\subsection{Microscopical Findings}

In the $5^{\text {th }}$ day ( $\mathrm{HH} \mathrm{26)}$ of development, it has been observed that the liver is shaped at cardio-hepatic zone in close relation with embryonic heart. The cells that will form hepatocytes are loosely organized and the sinusoids has begun to shape. At the lumen of sinusoids, blood cells, and at the walls, endothelial cells have been observed (Figure 2). It has been observed that hepatocytes are cubicle or low prismatic in shape. Hepatocytes clustering between sinusoids compose the liver parenchyma by spreading in dendriform shape. Also, mitotic hepatocytes have been observed (Figure 2). At the $6^{\text {th }}$ day of development (HH 28) it has been observed that the $2^{\text {nd }}$ lobe has formed (Figure 3) and hepatocytes has become tightly organized. Accompanied with this status, blood cells and increased liver sinusoidal spaces have been observed. Endothelial cells lining on the sinusoidal walls have been in evidence (Figure 4).

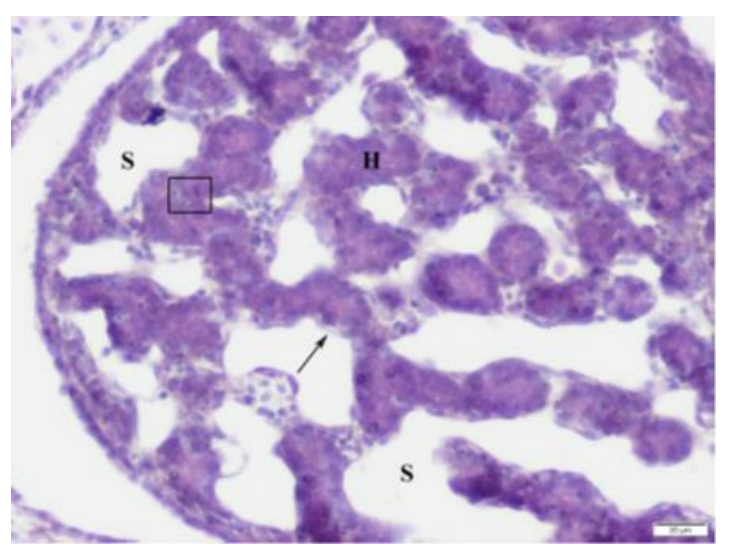

Figure 2. Liver tissue at $5^{\text {th }}$ day of development. Hepatocyte clusters $(\mathrm{H})$, endothelial cells $(\rightarrow)$, sinusoids (S), mitosis (口). H\&E, Bar $20 \mu \mathrm{m}$.

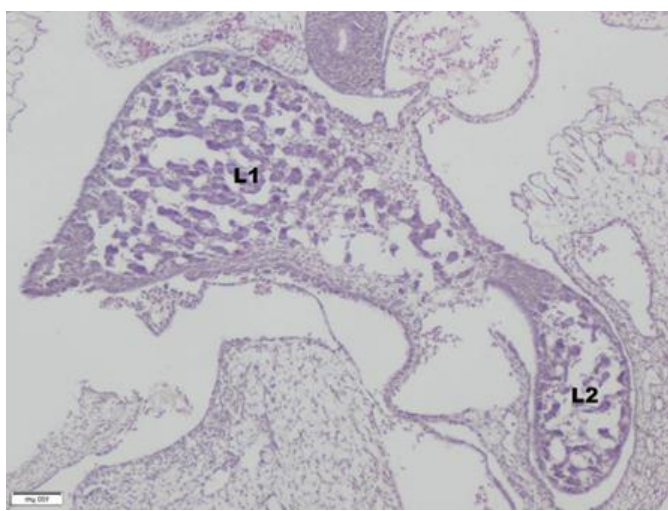

Figure 3. lobe 1 (L1) and lobe 2 (L2) at the $6^{\text {th }}$ day of development. H\&E, Bar $100 \mu \mathrm{m}$.

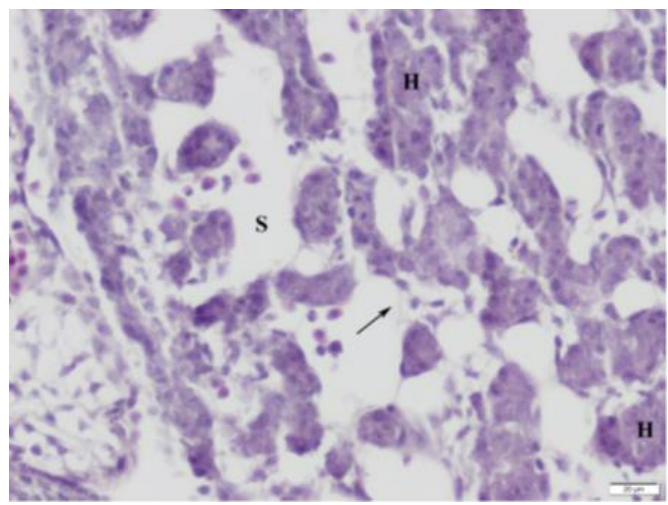

Figure 4 . at the $6^{\text {th }}$ day of development, hepatocytes are tightly organised and the number of sinusoids increased. Sinusoids (S), hepatocyte clusters $(\mathrm{H})$, endothelium $(\rightarrow)$. $\mathrm{H} \& \mathrm{E}$, Bar $20 \mu \mathrm{m}$.

At the $7^{\text {th }}$ day of development ( $\left.\mathrm{HH} 29\right)$, the formation of $3^{\text {th }}$ lobe, increase in hepatocyte count, the lumen of the sinusoids blood cells and the wall endothelial cells have been observed (Figure 5A). It has been seen that the hepatocytes spread in dendriform shape and compose the liver parenchyma, and sinusoids are formed in beam shaped structure from vena centralis zone (Figure $5 B)$. 


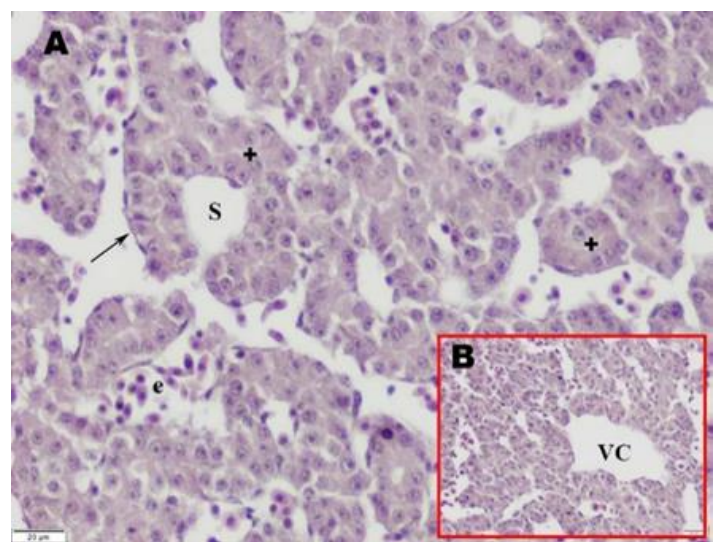

Figure 5. Liver tissue at $7^{\text {th }}$ day of development. (A), Dendriform shaped liver cords $(+)$, Sinusoids (S), Endothelial cells $(\rightarrow)$, Eritrocytes (e). (B), Vena Centralis (VC). H\&E, Bar $20 \mu \mathrm{m}$.

In this stage, it has been identified that the hepatocytes obtain cubic or low prismatic in shape. The $8^{\text {th }}$ day of development is similar to the $7^{\text {th }}$ day (Figure 6). After the $8^{\text {th }}$ day, organogenesis is completed and growing phase has started.

\subsection{Immunohistochemical Findings}

At the $5^{\text {th }}$ day of development, it has been observed that eNOS and iNOS immunoreactivity

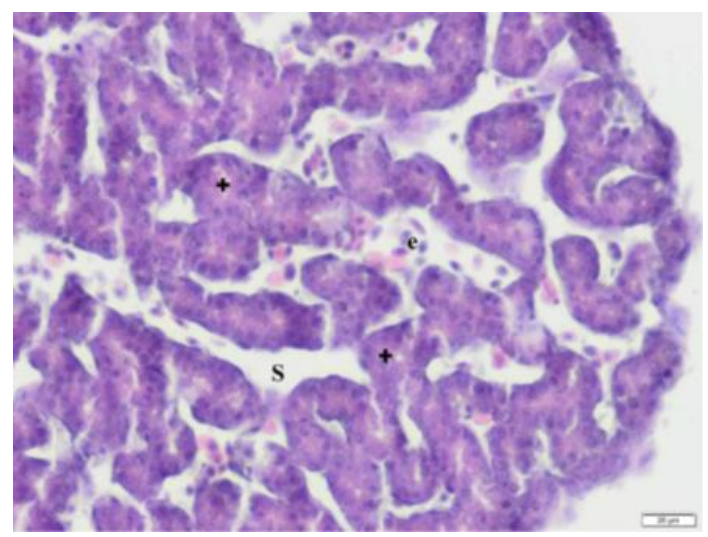

Figure 6. Liver tissue at $8^{\text {th }}$ day of development. Sinusoids (S), Eritrocytes (e), Hepatocytecords (+). H\&E, Bar $20 \mu \mathrm{m}$.

are present weakly and there is staining at the liver peripheral cells in general. After the $6^{\text {th }}$ day, the staining has increased, and with the $7^{\text {th }}$ day, eNOS staining becomes stronger than the iNOS staining (Figure 7). There is very little or no Laminin immunoreactivity at the $5^{\text {th }}$ day of development. After $6^{\text {th }}$ day, staining has increased and it has been observed that staining is very intense at the cells forming the hepatic cords.

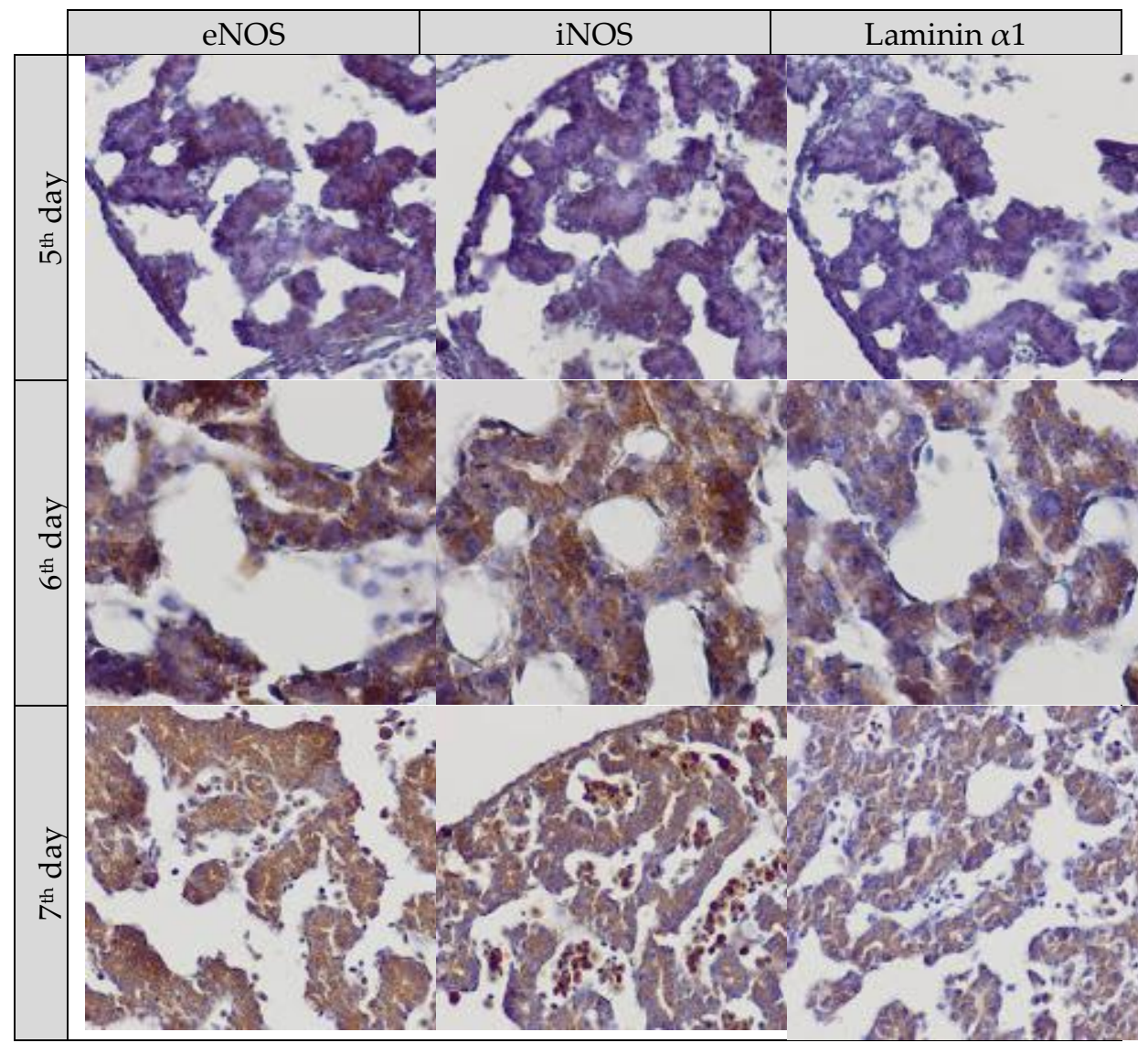

Figure 7. eNOS, iNOS and Laminin $\alpha 1$ staining at liver development stages (HH26, 28, 29). Bar $20 \mu \mathrm{m}\left(5^{\text {th }}\right.$ and $7^{\text {th }}$ days), Bar $10 \mu \mathrm{m}$ (6 $6^{\text {th }}$ day). 


\section{Discussion}

In the chick liver organogenesis, hepatic endoderm reproduces with mitosis and forms the hepatic cords of the liver. This morphogenesis that happens after the induction is specific to the species [33] and it has been known that this signal used for the induction is similar to the mouse liver development [34]. In this study, at the developing chick liver, distribution of eNOS and iNOS enzymes and the correlation of Laminin $\alpha 1$ with this enzyme have been examined.

Suksewang et al. [35] have stated that liver development of chick embryo starts in a day with hepatoblast differentiation and subsequently, at the $5^{\text {th }}, 6^{\text {th }}$ and $7^{\text {th }}$ days, $1^{\text {st }}, 2^{\text {nd }}$ and $3^{\text {rd }}$ lobe will be formed and liver will enter a very fast growing stage. The results of our study on daily basis are very similar to that of Suksewang et al.

It has been known that $\mathrm{NO}$ is an important molecule for the development of many organs. Ilentile at al. [36] have proved that $\mathrm{NO}$ is an important factor for the retinal development, and Uçar [37] indicates that NO is also needed for the lung development. Our findings are very similar to Uçar's [37], as eNOS activity is stronger than iNOS activity. On the contrary, while eNOS and iNOS activities have increased at the last days of the liver development, the activity in the lung has decreased according to Uçar's work. Liu and Feng [38] have showed that eNOS production starts at the early organogenesis in the heart of mice and maintains the high levels until the $13.5^{\text {th }}$ day, and any changes of the eNOS production have resulted in the congenital heart anomalies. At our study, similar to Liu and Feng, eNOS production has started at early liver organogenesis and has increased as the development improves.

It has been known that eNOS is continually expressed and with little stimulus, it will produce little amount of NO. Furthermore, NO which is produced with the eNOS protects the liver homeostasis and keeps liver safe from the pathological events [39]. Nowicki et al. [40] has examined and found that at the $18^{\text {th }}$ and $20^{\text {th }}$ day of development (near birth) eNOS expression continues to remain at lower levels, starts to increase with birth and it reaches maximum levels on adult rats. At this study, there is no data to be shown about eNOS in early stages of liver development, and the increase in eNOS after birth is associated with the increased blood flow in the liver. eNOS staining intensity is higher at the liver sinusoids. Cox et al. [41] has worked with some NO activators and inhibitors and they have examined the correlation of liver size with $\mathrm{NO}$ concentration in early zebrafish liver development. As a result, they found that normal levels of NO are essential for the liver development, but no data about NO distribution in the early liver developmental stage has been presented.

Hepatocyte cells make little amount of iNOS expression at normal conditions, but with events like the hemorrhagic shock or ischemiareperfusion damage, iNOS levels in the liver reaches very high levels. It has been put forward that the main reason is defending the liver from incoming liver damage [42]. Bloch et al. [42] has shown that eNOS and iNOS expressions have increased with time in mice heart development, eNOS staining is higher compared with the iNOS staining and as the development continues, iNOS staining is fainter compared to eNOS staining. In the literature review, no publication about the correlation of iNOS distribution with liver development has been found.

It has been known that $\mathrm{NO}$ can regulate the extracellular matrix (ECM) synthesis [43, 44], ECM can also carry the signals like cell proliferation, migration and differentiation events, which have important roles on tissue and organ development together with organ remodeling [45]. For the normal development of the liver, it has been found that ECM composition is a critical factor for epithelial-mesenchymal interaction [33]. During the liver development, it has been seen that periportal zone which densifies with undifferentiated cell population, is richer than other zones in terms of laminin, and any changes at the laminin concentration affect the liver development in a negative way [46]. Williams et al. [47] has indicated that laminin can increase liver regeneration in case of a liver damage. At the in vitro studies, it has been shown that laminin rich surfaces can support cell migration and have a key role at the cell differentiation [48]. It has been considered that the laminins constitute a special part of the hepatic cell niche of the human and 
mouse and it is thought that laminins play a role in maintaining this characteristic [49]. Rialas et al. [50] made studies with PC12 cell lines and concluded that nitric oxide is an important molecule for laminin signal transduction mechanism, because $\mathrm{NO}$ is inhibited laminin regulated neurite outgrowth. In addition, Meesters et al. [51] indicated that NO can induce the ECM synthesis and can accelerate bone healing.

At the embryo, cellular communication at the organogenesis stage and the signal molecules which help this communication are important in many aspects. In this stage, detection of specific cell factors that have a role on tissue and organ remodeling related mechanisms can be beneficial for a molecular level approach.

\section{References}

[1] Duarte, S.; Baber, J.; Fujii, T. Coito, A.J. Matrix Metalloproteinases in Liver Injury, Repair and Fibrosis, Matrix Biology, 2015; 44-46, 147-156.

[2] Langiewicz, M.; Schlegel, A.; Saponara, E.; Linecker, M.; Borger, P.; Graf, R.; Humar, B.; Clavien, P.A. Hedgehog Pathway Mediates Early Acceleration of Liver Regeneration Induced by a Novel Two-Staged Hepatectomy in Mice, Journal of Hepatology, 2017; 66(3): p. 560-570.

[3] Drews, U., Color Atlas of Embryology; Thieme, 1995; pp.383.

[4] Gilbert, S.F., Developmental Biology; Sinauer Associates INC: Massachusetts, USA, 2012.

[5] Kitta, R.; Kuwamoto, M.; Yamahama, Y.; Mase, K.; Sawada, H. Nitric Oxide Synthase During Early Embryonic Development in Silkworm Bombyx mori: Gene Expression, Enzyme Activity, And Tissue Distribution. Development, Growth \& Differentiation, 2016, 58(9), 750-756.

[6] Ribeiro, M.O.; Antunes, E.; de Nucci, G.; Lovisolo, S.M.; Zatz, R. Chronic Inhibition of Nitric Oxide Synthesis. A New Model of Arterial Hypertension, Hypertension, 1992; 20(3), 298-303.

[7] Bruckdorfer, R. The Basics About Nitric Oxide, Molecular Aspects of Medicine, 2005; 26(1-2), 3-31.

[8] Majid, D.S.; Kopkan, L. Nitric Oxide and Superoxide Interactions in the Kidney and Their Implication in The Development of Salt-Sensitive Hypertension. Clinical and Experimental Pharmacology \& Physiology, 2007; 34(9), 946-52.
[9] Lepetsos, P.; Papavassiliou, A.G. ROS/Oxidative Stress Signaling in Osteoarthritis, Biochimica et Biophysica Acta (BBA) - Molecular Basis of Disease, 2016; 1862(4), 576-591.

[10] Leadsham, J.E.; Gourlay, C.W. Cytoskeletal Induced Apoptosis in Yeast, Biochimica et Biophysica Acta (BBA) - Molecular Cell Research, 2008; 1783(7), 1406-1412.

[11] Cheng, H.; Wang, L.; Mollica, M.; Re, A.T.; Wu, S.; Zuo, L. Nitric Oxide in Cancer Metastasis, Cancer Letters, 2014; 353(1), 1-7.

[12] Hsu, Y.-C.; Hsiao, M.; Chien, Y.W.; Lee W.-R., Exogenous Nitric Oxide Stimulated Collagen Type I Expression and TGF- $\beta 1$ Production in Keloid Fibroblasts by a cGMP-Dependent Manner, Nitric Oxide, 2007; 16(2), 258-265.

[13] Brennan, P.A.; Palacios-Callender, M.; Umar, T.; Tant, S.; Langdon, J.D. Expression of Type 2 Nitric Oxide Synthase and P21 in Oral Squamous Cell Carcinoma, International Journal of Oral and Maxillofacial Surgery, 2002; 31(2), 200-205.

[14] Collu, F.; Gurcu, B. NO İnhibisyonunun Gelişen Piliç Embriyosu Karaciğer Dokusu Üzerine Etkisinin Histolojik, Histokimyasal ve İmmünohistokimyasal Açıdan İncelenmesi, in Biology, Manisa Celal Bayar Üniversitesi, 2016; p. 64. Tez

[15] Beqaj, S.; Jakkaraju, S.; Mattingly, R.R.; Pan, D.; Schuger, L. High RhoA Activity Maintains the Undifferentiated Mesenchymal Cell Phenotype, Whereas RhoA Down-Regulation by Laminin-2 Induces Smooth Muscle Myogenesis, The Journal of Cell Biology, 2002; 156(5), 893-903.

[16] Bonnans, C.; Chou, J.; Werb, Z. Remodelling the Extracellular Matrix in Development and Disease, Nature Reviews. Molecular Cell Biology, 2014; 15(12), 786-801.

[17] Gürcü, B. Balb/c Tipi Farelerde Metanefroz Gelişirken Farklılaşan Hücrelerin Işı-Elektron Mikroskobu ile Morfolojilerinin ve Glikozaminoglikanlarının Belirlenmesi, in Biology, Ege Üniversitesi, Bornova, 2002; p. 90. Tez

[18] Hohenester, E.; Yurchenco, P.D. Laminins in Basement Membrane Assembly, Cell Adhesion \& Migration, 2013; 7(1), 56-63.

[19] Kelley, L.C.; Lohmer, L.L.; Hagedorn, E.J.; Sherwood, D.R. Traversing the Basement Membrane In 
Vivo: a Diversity of Strategies, The Journal of Cell Biology, 2014; 204(3), 291-302.

[20] Miner, J.H.; Li, C.; Mudd, J.L.; Go, G.; Sutherland, A.E. Compositional and Structural Requirements for Laminin and Basement Membranes During Mouse Embryo Implantation and Gastrulation, Development, 2004; 131(10), 2247-56.

[21] Aumailley, M.; Bruckner-Tuderman, L.; Carter, W.G.; Deutzmann, R.; Edgar, D.; Ekblom, P.; Engel, J.; Engvall, E.; Hohenester, E.; Jones, J.C.; Kleinman, H.K.; Marinkovich, M.P.; Martin, G.R.; Mayer, U.; Meneguzzi, G.; Miner, J.H.; Miyazaki, K.; Patarroyo, M.; Paulsson, M.; Quaranta, V.; Sanes, J.R.; Sasaki, T.; Sekiguchi, K.; Sorokin, L.M.; Talts, J.F.; Tryggvason, K.; Uitto, J.; Virtanen, I.; von der Mark, K.; Wewer, U.M.; Yamada, Y.; Yurchenco, P.D. A Simplified Laminin Nomenclature, Matrix Biology, 2005; 24(5), 326-32.

[22] Miner, J.H. Laminins and Their Roles in Mammals, Microscopy Research and Technique, 2008; 71(5), 349-56.

[23] Albert, E.; The Extracellular Matrix in Development. In the Organization of the Early Vertebrate Embryo; Nikolas, Z., Editor; Plenum Press: New York, 1995; pp. 149-167.

[24] Rozario, T.; DeSimone, D.W. The Extracellular Matrix in Development and Morphogenesis: a Dynamic View, Developmental Biology, 2010; 341(1), 126-40.

[25] Brakebusch, C.; Fassler, R. The Integrin-Actin Connection, an Eternal Love Affair, the EMBO Journal, 2003; 22(10), 2324-33.

[26] Tkachenko, E.; Rhodes, J.M.; Simons, M. Syndecans: New Kids on The Signaling Block, Circulation Research, 2005; 96(5), 488-500.

[27] O'Sullivan, S.; Medina, C.; Ledwidge, M.; Radomski, M.W.; Gilmer, J.F. Nitric Oxide-Matrix Metaloproteinase-9 Interactions: Biological and Pharmacological Significance--NO and MMP-9 Interactions, Biochimica et Biophysica Acta, 2014; 1843(3), 603-17.

[28] Mikuz, G. Testicular Torsion: Simple Grading for Histological Evaluation of Tissue Damage, Applied Pathology, 1985; 3(3), 134-9.

[29] Nguyen, C.Q.; Hall, D.H.; Yang, Y.; Fitch, D.H. Morphogenesis of the Caenorhabditis elegans Male Tail Tip, Developmental Biology, 1999; 207(1), 86-106.
[30] Stadelmann, C.; Lassmann, H. Detection of Apoptosis in Tissue Sections, Cell Tissue Research, 2000; 301(1), 19-31.

[31] Vivek, C.; Veeraiah, K.; Padmavathi, P.; Rao, H.D.; Bramhachari, P.V. Acute Toxicity and Residue Analysis of Cartap Hydrochloride Pesticide: Toxicological Implications on the Fingerlings of Fresh Water Fish Labeo rohita, Biocatalysis and Agricultural Biotechnology, 2016; 7: pp.193-201.

[32] Dhage, P.A.; Kamble, L.K.; Bhargava, S.Y. Localization and Distribution of Superoxide Dismutase1 in the Neural Tube Morphogenesis of Chick Embryo, International Journal of Developmental Neuroscience, 2017; 56: p. 1-9.

[33] Tatsumi, N.; Miki, R.; Katsu, K.; Yokouchi, Y. Neurturin-GFR $\alpha 2$ Signaling Controls Liver Bud Migration Along the Ductus Venosus in the Chick Embryo, Developmental Biology, 2007; 307(1): pp.14-28.

[34] Nakayama, M.; Matsumoto, K.; Tatsumi, N.; Yanai, M.; Yokouchi, Y. Id3 is Important for Proliferation and Differentiation of the Hepatoblasts During the Chick Liver Development, Mechanisms of Development, 2006; 123(7): p. 580-90.

[35] Suksaweang, S.; Lin, C.-M.; Jiang, T.-X.; Hughes, M.W.; Widelitz, R.B.; Chuong, C.-M. Morphogenesis of Chicken Liver: Identification of Localized Growth Zones and the Role of $\beta$-catenin/Wnt in Size Regulation, Developmental Biology, 2004; 266(1): pp.109-122.

[36] Ientile, R.; Malecka, B.; Picciurro, V.; Naso, A.; Pedale, S.; Macaione, S. Nitric Oxide Synthase in Chick Embryo Retina During Development, FEBS Letters, 1996; 379(1): pp.82-84.

[37] Uçar, E. Nitrik Oksit İnhibisyonunun Piliç Embriyosu Akciğer Gelişimi Üzerine Etkisi, in Fen Bilimleri Enstitüsü, Zooloji Anabilim Dalı, Celal Bayar Üniversitesi: Manisa, 2014; Tez.

[38] Liu, Y.; Feng, Q. NOing The Heart: Role of Nitric Oxide Synthase-3 in Heart Development, Differentiation, 2012; 84(1): p. 54-61.

[39] Iwakiri, Y.; Kim, M.Y. Nitric Oxide in Liver Diseases, Trends in Pharmacological Sciences, 2015; 36(8): pp.524-536.

[40] Nowicki, M.J.; Shi, D.; Cai, Z.; Bishop, P.R.; May, W.L. Developmental Expression of Endothelial Nitric Oxide Synthase (eNOS) in The Rat Liver, Pediatric Research, 2003; 54(5): pp.732-8. 
[41] Cox, A.G.; Saunders, D.C.; Kelsey, P.B., Jr.; Conway, A.A.; Tesmenitsky, Y.; Marchini, J.F.; Brown, K.K.; Stamler, J.S.; Colagiovanni, D.B.; Rosenthal, G.J.; Croce, K.J.; North, T.E.; Goessling, W. S-nitrosothiol Signaling Regulates Liver Development and Improves Outcome Following Toxic Liver Injury, Cell Reports, 2014; 6(1): p. 56-69.

[42] Taylor, B.S.; Alarcon, L.H.; Billiar, T.R. Inducible Nitric Oxide Synthase in the Liver: Regulation and Function, Biochemistry (Mosc), 1998; 63(7): pp.766-81.

[43] Myers, P.R.; Tanner, M.A. Vascular Endothelial Cell Regulation of Extracellular Matrix Collagen: Role of Nitric Oxide, Arteriosclerosis, Thrombosis, and Vascular Biology, 1998; 18(5): pp.717-22.

[44] Trachtman, H.; Futterweit, S.; Singhal, P. Nitric Oxide Modulates the Synthesis of Extracellular Matrix Proteins in Cultured Rat Mesangial Cells, Biochemical and Biophysical Research Communications, 1995; 207(1): pp.120-125.

[45] Xing, Q.; Zhang, L.; Redman, T.; Qi, S.; Zhao, F. Nitric Oxide Regulates Cell Behavior on an Interactive Cell-Derived Extracellular Matrix Scaffold, Journal of Biomedical Materials Research. Part A, 2015; 103(12): p. 3807-14.

[46] Kanninen, L.K.; Harjumäki, R.; Peltoniemi, P.; Bogacheva, M.S.; Salmi, T.; Porola, P.; Niklander, J.; Smutný, T.; Urtti, A.; Yliperttula, M.L.; Lou, Y.-R. Laminin-511 and laminin-521-Based Matrices for Efficient Hepatic Specification of Human Pluripotent Stem Cells, Biomaterials, 2016; 103: pp.86-100.
[47] Williams, M.J.; Boulter, L.G.; Lu, W.Y.; Bird, T.G.; Fujiwara, H.; Watt, F.M.; Ffrench-Constant, C.; Forbes, S.J. 4 the Extracellular Matrix Protein Laminin Alpha 5 Regulates the Behaviour of Hepatic Progenitor Cells in Regenerating Mouse Liver, Journal of Hepatology, 2013; 58: pp.S2-S3.

[48] Lee, D.Y.; Lee, J.H.; Ahn, H.-J.; Oh, S.H.; Kim, T.H.; Kim, H.-B.; Park, S.-W.; Kwon, S.K. Synergistic Effect of Laminin and Mesenchymal Stem Cells on Tracheal Mucosal Regeneration, Biomaterials, 2015; 44: p. 134-142.

[49] Govaere, O.; Wouters, J.; Petz, M.; Vandewynckel, Y.-P.; Van den Eynde, K.; Van den broeck, A.; Verhulst, S.; Dollé, L.; Gremeaux, L.; Ceulemans, A.; Nevens, F.; van Grunsven, L.A.; Topal, B.; Vankelecom, H.; Giannelli, G.; Van Vlierberghe, H.; Mikulits, W.; Komuta, M.; Roskams, T. Laminin-332 Sustains Chemoresistance and Quiescence as Part of the Human Hepatic Cancer Stem Cell Niche, Journal of Hepatology, 2016; 64(3): pp.609-17.

[50] Rialas, C.M.; Nomizu, M.; Patterson, M.; Kleinman, H.K.; Weston, C.A.; Weeks, B.S. Nitric Oxide Mediates Laminin-Induced Neurite Outgrowth in PC12 Cells, Experimental Cell Research, 2000; 260(2): pp.268-276.

[51] Meesters, D.M.; Neubert, S.; Wijnands, K.A.P.; Heyer, F.L.; Zeiter, S.; Ito, K.; Brink, P.R.G.; Poeze, M. Deficiency of Inducible and Endothelial Nitric Oxide Synthase Results in Diminished Bone Formation and Delayed Union and Nonunion Development, Bone, 2016; 83: pp.111-118. 